Share Your Innovations through JACS Directory

\title{
Bandgap Tuning of High Mobility Magnetron Sputtered Copper (I) Oxide Thin Films for Perovskite Solar Cell Applications

\author{
M.I. Hossain¹, B. Aïssa ${ }^{1,2, *}$, A. Bentouaf ${ }^{3,4}$, S. Mansour ${ }^{1}$ \\ ${ }^{1}$ Qatar Environment and Energy Research Institute (QEERI), Hamad Bin Khalifa University (HBKU), Qatar Foundation, P.O. Box 5825, Doha, Qatar.
} ${ }_{2}^{2}$ MPB Communications Inc., Space \& Photonics Division, 151 Hymus Boulevard, Pointe Claire, Quebec, Canada.

${ }^{3}$ Faculty of Technology, University of Doctor Moulay Tahar, Saida, 20000, Algeria.

${ }^{4}$ Laboratory of Physical Chemistry of Advanced Materials, University of Djillali Liabes, BP 89, Sidi-Bel-Abbes 22000, Algeria.

\section{A R T I L L D E T A I L S}

Article history:

Received 23 February 2021

Accepted 02 March 2021

Available online 17 March 2021

\section{Keywords:}

Thin Films

$\mathrm{Cu}_{2} \mathrm{O}$

DC-Reactive Sputtering

Perovskite Solar Cells

\begin{abstract}
A B S T R A C T
We report on the successful growth optimization of an inorganic p-type copper oxide $\left(\mathrm{Cu}_{2} \mathrm{O}\right)$ thin films for various energy applications. First, $\mathrm{Cu}_{2} \mathrm{O}$ thin films of a typical thickness of $100 \mathrm{~nm}$ are deposited on fluorine-doped tin oxide (FTO) coated glass substrates by DC-reactive magnetron sputtering, followed by their in-depth characterization with different techniques, including scanning electron and atomic force microscopies, UV-Vis, X-ray diffraction and photoelectron spectroscopies, to probe their structural, optical, and morphological properties. Surface topology analysis revealed homogeneous, compact, and uniform sputtered deposited films. The as deposited films layers have shown a preferential crystal orientation of (111) and a stoichiometry of $\mathrm{CuO}$, at the surface, which is believed to be mainly due to the oxidization effect of the non-capsulated surface, while a short-duration argon etching $(\sim 5 \mathrm{~s})$ has revealed the growth of $\mathrm{Cu}_{2} \mathrm{O}$ films stoichiometry. Finally, during the reactive plasma deposition, films were grown under nitrogen gas flow to improve their hole-mobility, followed by a systematic annealing at various temperatures ranging from 100 to $250{ }^{\circ} \mathrm{C}$ to improve their crystalline structure. Hall effect measurement confirmed that the $\mathrm{Cu}_{2} \mathrm{O}$ thin film are p-type, with extremely high electronic properties, including an electrical conductivity of $2.6 \times 10^{2} \mathrm{~S} / \mathrm{cm}$, a hole mobility of about $30 \mathrm{~cm}^{2} /$ Vs and a charge carrier density around $5 \times 10^{19} \mathrm{~cm}^{-3}$, making them a serious candidate for a hole transport layer in perovskite solar cells.
\end{abstract}

\section{Introduction}

Cuprous oxide $\left(\mathrm{Cu}_{2} \mathrm{O}\right)$ is a well-established p-type material and its conductivity is directly correlated with the oxygen rich or poor layers due to the variation in growth processes [1]. Such growth processes usually result in copper (I) oxide $\mathrm{Cu}_{2} \mathrm{O}$ and copper (II) oxide $\mathrm{CuO}$ (i.e. cupric oxide) $[2,3]$ films mainly due to the oxidization process of copper films. The optical properties vary for both $\mathrm{Cu}_{2} \mathrm{O}$ and $\mathrm{CuO}$ as reported previously [47] mainly due to the growth process resulting in rich or poor oxygen bonding. It has been reported that $\mathrm{Cu}_{2} \mathrm{O}$ confirms an optical bandgap between 2.10 and $2.60 \mathrm{eV}[4,5]$, whereas for $\mathrm{CuO}$, it is between 1.3 and 2.1 $\mathrm{eV}[6,7]$. Such optical properties open the path to use such layers as a buffer for energy conversion devices. In general, copper oxide films show high transparency with light absorbing capability at wavelengths below $600 \mathrm{~nm}$, whereas metal rich oxide films absorbs strongly in the visible spectrum range [2].

As reported by Richardson [8], such oxide films can be used for architectural and aerospace applications because of the capability to tune the optical properties. In addition, their high light transmission along with their lower electrical resistivity makes these films suitable as light window layer for optoelectronic devices, where their carrier transportation helps to generate electricity using energy conversion devices. However, it has been found that cuprous oxide can result in higher electrical resistivity due to growth conditions and/or post-oxidization effect [1,9].

Previously, Hossain et al. numerically confirmed $\mathrm{Cu}_{2} \mathrm{O}$ as an alternative hole transport material (HTM) with a power conversion efficiency of $24 \%$ [10]. Later, some experimental studies also confirmed the usage of this material to replace the expensive Spiro-OMETAD layer [11-16] as a HTM. Due to the perfectly aligned valance band, carrier injection becomes ideal from the absorber layer. Many attempts have been conducted to fabricate Schottky junction, hetero-junction, and homo-junction devices using $\mathrm{Cu}_{2} \mathrm{O}$

*Corresponding Author:brahim.aissa@mpbc.ca(Brahim Aissa) as a light harvesting layer [17]. However, the limitation arises mainly from the high bandgap $(>2 \mathrm{eV}$ ) which results in poor light absorption capability in longer range with a very low short circuit current $\left(\mathrm{J}_{\mathrm{sc}}\right)$ [17].

Various techniques have been used to fabricate $\mathrm{Cu}_{2} \mathrm{O}$ thin films, including magnetron sputtering [18], copper oxidation [19], and atomic layer deposition (ALD) [20]. Unintentionally doped $\mathrm{Cu}_{2} \mathrm{O}$ films are naturally $\mathrm{p}$-type due to the native defects identified as negatively charged copper vacancies $\left(\mathrm{V}^{\prime} \mathrm{Cu}\right)$ rather than interstitial oxygen $\left(\mathrm{O}_{\mathrm{i}}^{\prime}\right)$. Also, nitrogen doping has been used to prepare samples containing high density of holes of about $10^{18} \mathrm{~cm}^{-3}[21,22]$.

The aim of our work is to optimize the DC-reactive magnetron sputtering growth of $\mathrm{Cu}_{2} \mathrm{O}$ films at different temperatures by probing their structural, morphological, and electrical properties. The main focus was put on the evolution of preferred crystalline orientation as a function of the process temperatures.

\section{Experimental Methods}

All chemicals were purchased from Sigma Aldrich ${ }^{\mathrm{TM}}$ and used as received. Fluorine doped tin oxide (FTO) coated commercial borosilicate glass substrates with dimensions of $3 \mathrm{~cm} \times 3 \mathrm{~cm} \times 1.5 \mathrm{~mm}$ were used in the present work. The pre-coated FTO with a $100 \mathrm{~nm}$ thick layer has led to a very low sheet resistance of about $\sim 10 \Omega$ /square. Prior to the deposition, the substrates were systematically cleaned up inside an ultrasonic bath for 5 min using acetone, isopropanol, and deionized water. Samples were then dried with nitrogen blow and used immediately for deposition. $\mathrm{Cu}_{2} \mathrm{O}$ films were deposited by DC magnetron sputtering (Torr International's MagSput ${ }^{\mathrm{TM}}$ series CRC 600 ) with a power density of $1.5 \mathrm{~W} / \mathrm{cm}^{2}$, using $\mathrm{Cu}$ target $\left(99.999 \%\right.$ purity), at various temperatures ranging from $100^{\circ} \mathrm{C}$ to $250{ }^{\circ} \mathrm{C}$, under oxygen and nitrogen flow, with a background pressure of about 10 mTorr. The chamber base pressure was about $10^{-5}$ Torr as pumped down by the turbo molecular pump. $\mathrm{Cu}_{2} \mathrm{O}$ films of a typical thickness of $100 \mathrm{~nm}$ were thus grown, and their structural and morphological characterizations show that the deposited film quality is 
rather homogeneous over the entire sample surface with an optimized optical and structural property. The deposition time was kept at $30 \mathrm{~min}$, the relative oxygen to total flow ratio $\left(\mathrm{r}\left(\mathrm{O}_{2}\right)=\mathrm{O}_{2}\right.$ / Ar flows) at $11.5 \%$ (namely $15 \mathrm{sccm}$ of $\mathrm{O}_{2}$ vs. $120 \mathrm{sccm}$ of $\mathrm{Ar}$ and $10 \mathrm{sccm}$ of $\mathrm{N}_{2}$ ), while the temperature deposition (TD) was varied from 100 to $250{ }^{\circ} \mathrm{C}$ in step of 50 ${ }^{\circ} \mathrm{C}$ (i.e. four TDs, namely $100,150,200$ and $250^{\circ} \mathrm{C}$ ). Perovskite layer was formed on the top of the by thermal evaporation technique from the source powder of $\mathrm{PbI}_{2}$ (Sigma-Aldrich) and $\mathrm{CH}_{3} \mathrm{NH}_{3} \mathrm{I}$ (Dyesol) by changing the ratio. The estimated thickness was checked using the crystal monitor of the system by changing the density and z-factor. It varied between 300 to $500 \mathrm{~nm}$ based on the ration of source powders.

\section{Results and Discussion}

\subsection{XRD Analysis}

The structural analysis of the sputtered thin films was performed by Xray diffractometer (XRD, Rigaku $\mathrm{XRD}^{\mathrm{TM}}$ ) at diffraction angles $2 \theta$, ranging from $10^{\circ}$ to $80^{\circ}$. Fig. 1 shows the XRD pattern obtained for four asdeposited films, at temperatures of $100{ }^{\circ} \mathrm{C}, 150{ }^{\circ} \mathrm{C}, 200^{\circ} \mathrm{C}$ and $250{ }^{\circ} \mathrm{C}$ (no annealing treatment was performed on these films after the deposition. XRD signal is shown after smoothing the signal with OriginLab ${ }^{\mathrm{TM}}$ software). The analysis shows a clear preferential growth tendency of the films along the (111) direction of $\mathrm{Cu}_{2} \mathrm{O}$ phase. For the samples grown at higher temperature, the (111) peak becomes more intense and starting from $200{ }^{\circ} \mathrm{C}$. The (211) phase orientation takes place (peak located at 42 degree). The (211) peak becomes then more intense with respect to the deposition temperature. These crystalline changes could be attributed to the coalescence induced grain growth during the temperature process where unlike the larger nuclei, the smaller ones can easily rotate in order to minimize the interfacial energy. Indeed, with increasing temperature, the atoms gain sufficient energy to be structurally reoriented within the crystal lattice leading thereby to a more stable structure with enhanced crystalline quality.

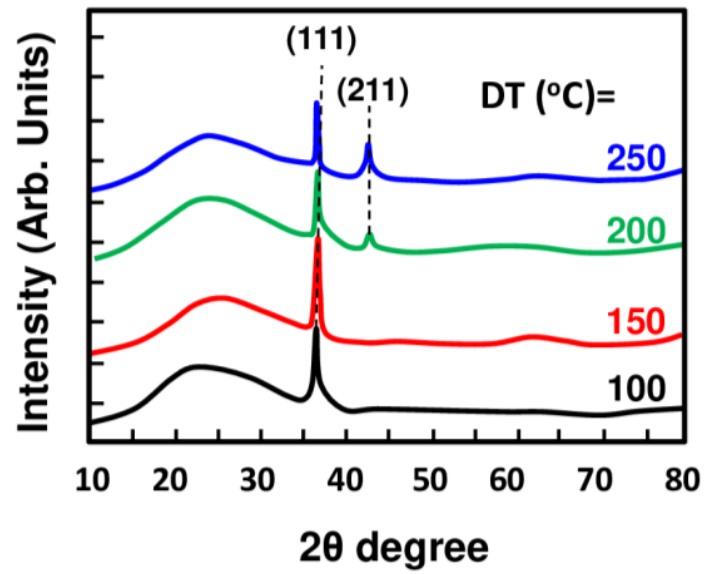

Fig. 1 Representative X-ray diffraction patterns of the $\mathrm{Cu}_{2} \mathrm{O}$ films grown at 100, 150, 200 and $250{ }^{\circ} \mathrm{C}$ without any post annealing process

The average crystallite size for each different orientation was estimated by the well-known Debye-Scherrer equation and summarized the crystalline sizes in Table 1 . All the calculated values are found in the range of $45-50 \mathrm{~nm}$.

Table 1 Crystallite size calculations

\begin{tabular}{lllll}
\hline $2 \theta$ & Measured FWHM & $\theta$ & FWHM (rad) & Crystallite Size (nm) \\
\hline 36 & 0.34 & 16.60 & 0.003393 & 45.48 \\
42 & 0.34 & 21.60 & 0.003254 & 48.90 \\
\hline
\end{tabular}

\subsection{XPS Analysis}

Surface analysis by X-ray photoelectron spectroscopy is performed on series of metal oxides using Escalab 250Xi (Thermo Fisher Scientific). The spectra analysis and fitting was conducted using Avantage software. The source is monochromatic Al $\mathrm{K}$ alpha and its energy is $1486.68 \mathrm{eV}$. The pass energy is $20 \mathrm{eV}$ for all narrow scans and $100 \mathrm{eV}$ for survey scans. Number of scans for each spectrum is 10 for high resolution spectra and 1 for survey spectra. The survey spectra showed a good quality metal oxide with some reduced presence of elements and carbon species contamination. Regarding the oxygen chemical states analysis, the carbon spectra fitting has been used to identify the amount of oxygen related to carbon species which can be deducted from the total oxygen to conclude the oxide related oxygen. The amounts of oxide related oxygen using Biesenger et al. [23] https://doi.org/10.30799/jtfr.026.21050101

method as well as all elemental atomic percentages have been measured The $\mathrm{Cu}_{2} \mathrm{O}$ films grown at the lowest employed temperature, namely 100 ${ }^{\circ} \mathrm{C}$, show the presence of $\mathrm{CuO}$ phase (note that all the other parameters were kept the same, including $\mathrm{O}_{2}, \mathrm{Ar}$ and $\mathrm{N}_{2}$ flow, deposition-time and power-density).XPS analysis reveals the presence of adsorbed oxygen and the presence of $\mathrm{Cu}_{2}{ }^{+}$atoms at the surface, as indicated by the satellite peak located at $951 \mathrm{eV}$. However, after Ar etching for about $30 \mathrm{~s}$, the XPS spectra indicate that the films have rather the typical stoichiometric composition of $\mathrm{Cu}_{2} \mathrm{O}$, as displayed in Fig. 2. The same behavior was then observed for the films grown at $150^{\circ} \mathrm{C}, 200^{\circ} \mathrm{C}$ and $250^{\circ} \mathrm{C}$.

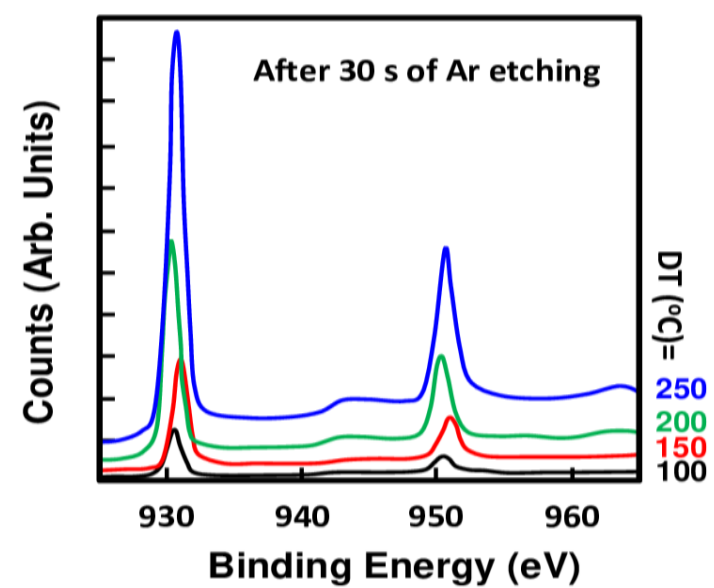

Fig. 2 Typical XPS spectra of $\mathrm{Cu}_{2} \mathrm{O}$ films grown at various temperatures, showing the stoichiometry of $\mathrm{Cu}_{2} \mathrm{O}$ material

\subsection{Surface Morphology Analysis by SEM}

The representative SEM micrographs of the as-deposited $\mathrm{Cu}_{2} \mathrm{O}$ films are displayed in Fig. 3. First, the films are shown to cover homogenously the entire surface of the glass substrates. For films grown at $100{ }^{\circ} \mathrm{C}$, small grains sizes of about $60 \mathrm{~nm}$ in diameter were the most observed ones, which is in good agreement with the XRD analysis. The grains are then found to be smaller with respect to the deposition temperatures, and are in the range of $50 \mathrm{~nm}, 40 \mathrm{~nm}$, and $30 \mathrm{~nm}$, for deposition temperatures of $150{ }^{\circ} \mathrm{C}, 200^{\circ} \mathrm{C}$ and $250^{\circ} \mathrm{C}$, respectively.

(a)

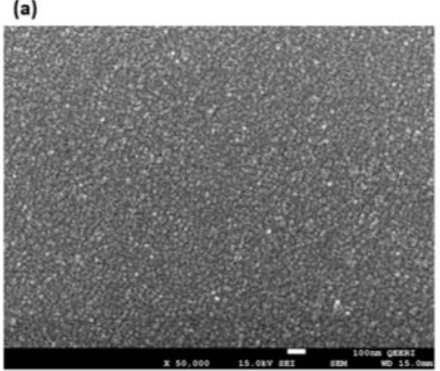

Fig. 3 Typical SEM micrographs of the copper oxide layers prepared on glass substrates, as deposited at (a) $100{ }^{\circ} \mathrm{C}$ and (b) $250{ }^{\circ} \mathrm{C}$

\subsection{Surface Topology Analysis by AFM}

The surface roughness of the as-deposited $\mathrm{Cu}_{2} \mathrm{O}$ films at $250^{\circ} \mathrm{C}$ has been investigated by means of atomic force microscopy. Clear change in the surface morphology was systematically observed with respect to the growth temperature, in agreement with SEM analysis. Fig. 4 shows the contact-mode AFM image of the $\mathrm{Cu}_{2} \mathrm{O}$ film as-deposited at $250{ }^{\circ} \mathrm{C}$ on glass substrate, showing an average RMS of $30.54 \mathrm{~nm}$.

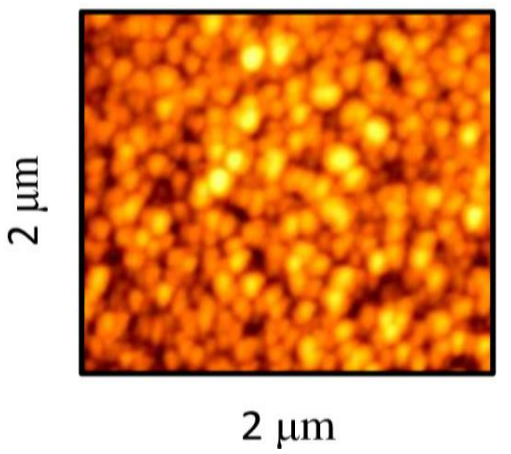

Fig. 4 Contacting mode AFM image of the $\mathrm{Cu}_{2} \mathrm{O}$ layer prepared on glass at $250{ }^{\circ} \mathrm{C}$ 


\subsection{Optical Characterization}

The optical properties of the as-deposited $\mathrm{Cu}_{2} \mathrm{O}$ films were also investigated through the UV-Vis spectroscopy (Jasco V100 ${ }^{\mathrm{TM}}$ ), in the range of 380-890 nm wavelengths. The obtained spectra are summarized in Fig. 5(a-d). As known, copper oxide is a direct bandgap semiconductor material [10]. We have found that the band gap is $2.56 \mathrm{eV}$ at $100{ }^{\circ} \mathrm{C}$, and decreased then to $2.50 \mathrm{eV}$ (and is stable at this value) for DT $\geq 150{ }^{\circ} \mathrm{C}$ is stable regardless to the temperature).

The $\mathrm{Cu}_{2} \mathrm{O}$ band gap was found to vary from $2.56 \mathrm{eV}$ for films deposited at $100{ }^{\circ} \mathrm{C}$ to $2.50 \mathrm{eV}$ for those deposited at DT $\geq 150{ }^{\circ} \mathrm{C}$. This bandgap variation is believed to be due to the strong dependence of electronic states on the effective exciton mass, in addition to the bandwidth changes, dielectric confinement, and possible quantum confinement [24].

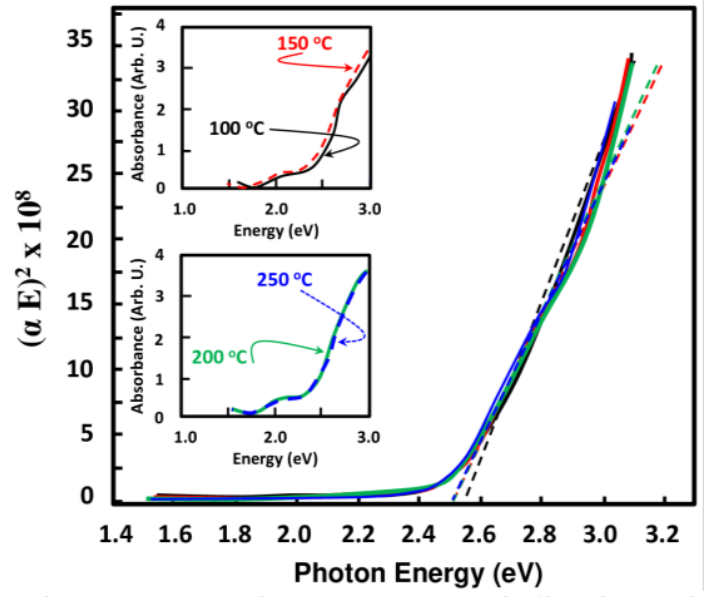

Fig. 5 Bandgap estimation of the various copper oxide films deposited on glass substrates at (a) $100{ }^{\circ} \mathrm{C}$, (b) $150^{\circ} \mathrm{C}$, (c) $200^{\circ} \mathrm{C}$, and (d) $250^{\circ} \mathrm{C}$

Generally, in polycrystalline semiconductors films, the optical absorption can be affected by many parameters, including the stoichiometric deviation such as the metal to oxygen ratio, grain size. Yet, the illustrated graphs displays rather continuous optical spectra, which could in fact happen due to the stability of the measured films during the characterization process (i.e. films degrade slowly) [24-26].

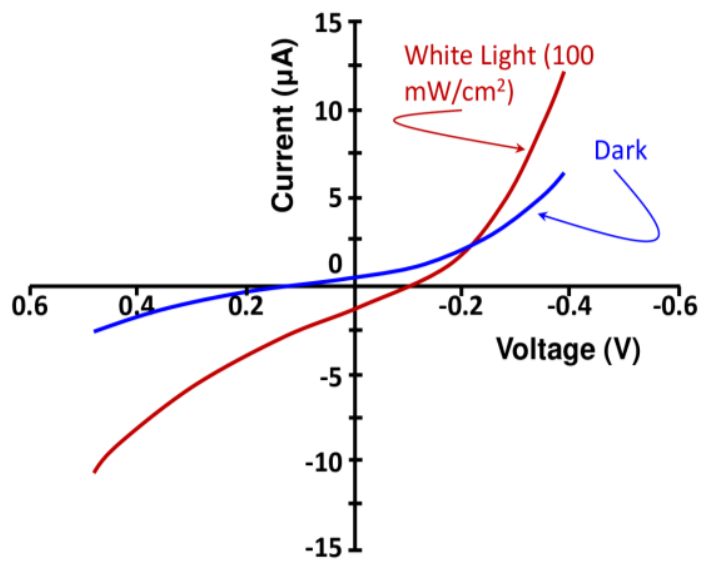

Fig. $6 \mathrm{I}-\mathrm{V}$ measurement of $\mathrm{Cu}_{2} \mathrm{O}$ based perovskite solar cells

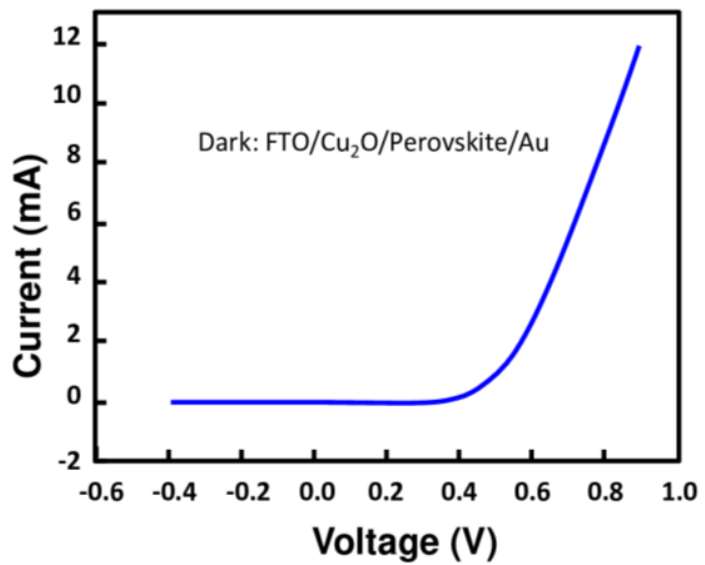

Fig. 7 Dark I-V measurement of $\mathrm{Cu}_{2} \mathrm{O}$ based perovskite solar cells https://doi.org/10.30799/jtfr.026.21050101

\subsection{Electrical Characterization}

Four-point measurements were conducted on the $\mathrm{Cu}_{2} \mathrm{O}$ films to measure their electrical surface conductivity, which was about $100 \mathrm{~S} / \mathrm{cm}$ for films grown at $100{ }^{\circ} \mathrm{C}$. Electrical conductivity was found to be less affected by the deposition-temperature. This average value is estimated somehow lower due most probably to the oxidation of the samples through their exposition to an open air for a long time. However, while a nitrogen doping was carried out during the reactive plasma sputtering of the films, electrical conductivity was improved by $100 \%$ and reached 200 $\mathrm{S} / \mathrm{cm}$. Table 2 summarizes the electrical properties of the deposited films at various temperatures. The $\mathrm{I}-\mathrm{V}$ characteristics of the cells were performed by photo electrochemical set. This is the most fundamental characterization tool to measure the conversion efficiency of a cell. The measured structure as shown in Figs. 6 and 7 is for FTO/ $\mathrm{Cu}_{2} \mathrm{O} /$ $\mathrm{CH}_{3} \mathrm{NH}_{3} \mathrm{PbI}_{3} / \mathrm{Au}$. All the structures showed a diode-like behavior for dark and under light. For this type of ETM free structure, current generation under illumination can be observed. Although the feasibility of such films for perovskite solar cell is clearly demonstrated in this work, an optimization step is highly needed to obtain higher photo conversion efficiency.

Table 2 Electrical properties of the $\mathrm{Cu}_{2} \mathrm{O}$ films as a function of the growth temperature and annealing process

\begin{tabular}{lll}
\hline & \multicolumn{2}{l}{ Electrical conductivity $(\mathrm{S} / \mathrm{cm})$} \\
\cline { 2 - 3 } TD $\left({ }^{\circ} \mathrm{C}\right)$ & Before annealing in $\mathrm{N}_{2}$ & After annealing in $\mathrm{N}_{2}$ \\
\hline 100 & 104 & 185 \\
150 & 106 & 189 \\
200 & 109 & 191 \\
250 & 115 & 200 \\
\hline
\end{tabular}

Electrical conductivity and Hall mobility $\left(\mu_{\mathrm{HALL}}\right)$ of the $\mathrm{Cu}_{2} \mathrm{O}$ films deposited at $250{ }^{\circ} \mathrm{C}$ after annealing in nitrogen were measured at room temperature with appropriate ohmic contacts. Van der Pauw technique $[27,28]$ was used to minimize the contact effects. The films were found to be p-type and the values of electrical conductivity, mobility of the charge carriers and carrier density measured were $216 \mathrm{~S} / \mathrm{cm}, 28.6 \mathrm{~cm}^{2} / \mathrm{Vs}$ and $4.72 \times 10^{19} \mathrm{~cm}^{-3}$, respectively. The carrier concentration values obtained from these measurements agree well with those reported so far [29-36] by DC magnetron sputtering techniques used in this study with minimal controlling deposition parameters is recorded. The enhancement of carrier concentration was due to the presence of copper vacancies in our films. Fig. 8 shows the corresponding PL measurement of different structures. Excitation wavelength at $680 \mathrm{~nm}$ was used to irradiate the films with an equal intensity. For PL measurement, FTO glass substrates were used to mimic the real device structure. A strong quenching of the PL intensity has been observed once integrating $\mathrm{Cu}_{2} \mathrm{O}$ as a hole transfer material, which is attributed to the better charge transport material quality.

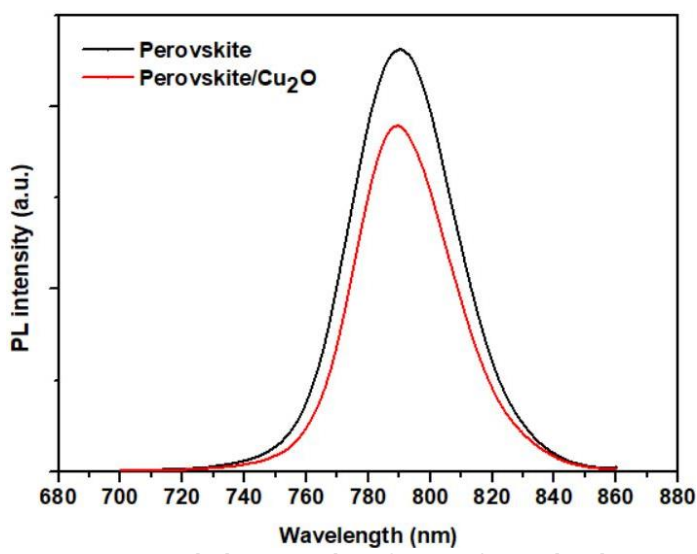

Fig. 8 PL measurement with clear quenching for $\mathrm{Cu}_{2} \mathrm{O}$ /perovskite layers

\section{Conclusion}

The synthesis of cuprous oxides $\left(\mathrm{Cu}_{2} \mathrm{O}\right)$ thin films by a direct current (DC) reactive magnetron sputtering technique has been demonstrated at various temperatures and their structural properties were systematically investigated, including crystal orientation, grain size and lattice parameters. Only two primary peaks corresponding to (111) cub and (200) ${ }^{\text {cub }}$ orientations indicating polycrystalline nature were found for all the deposited films. The relative peak intensity was found to be higher for increased deposition temperatures indicating thereby a better 
crystallinity. SEM analysis demonstrated that the films were compact throughout the entire sample surface, with no observed pinholes. The surface morphology of the films was strongly dependent on the deposition temperatures as a function of the film-thickness and changes from rough surface (grains of about $60 \mathrm{~nm}$ in diameter were measured at $100{ }^{\circ} \mathrm{C}$ ) to much smoother surface observed at higher deposition temperatures. This variation in DT can play a vital role in forming $\mathrm{Cu}_{2} \mathrm{O}$ films, which can be directly implemented as energy application layer (e.g. hole transport material) with no further fine-tuning. Although a photovoltaic effect was clearly observed; showing a short current of $2.61 \times 10^{-6} \mathrm{~A}$ and an open circuit voltage of $100 \mathrm{mV}$, the efficiency is quite small and further optimizations are needed to optimize the whole device. However, the films were found to be p-type, with extremely high electronic properties, such as an electrical conductivity above $2 \times 10^{2} \mathrm{~S} / \mathrm{cm}$, a hole mobility of about $30 \mathrm{~cm}^{2} / \mathrm{Vs}$ and a charge carrier density around $5 \times 10^{19} \mathrm{~cm}^{-3}$.

\section{Acknowledgement}

The authors gratefully acknowledge Qatar National Research Fund (QNRF), member of Qatar Foundation, for funding this work through the grant NPRP11S-0117-180330. Also, our thanks are due to QEERI Core Labs team for materials characterizations.

\section{References}

[1] R. Padyath, J. Seth, S.V. Babu, Deposition of copper oxide films by reactive laser ablation of copper formate in an r.f. oxygen plasma ambient, Thin Solid Films 239 (1994) 8-15.

[2] T.J. Richardson, J.L. Slack, M.D. Rubin, Electrochromism of copper oxide thin films, Proceedings of the $4^{\text {th }}$ International meeting on Electrochromism, Building Systems and Materials Division of the US Department of Energy, Uppsala, Sweden, 2000.

[3] H. Derin, K. Kantarli, Optical characterization of thin thermal oxide films on copper by ellipsometry, Appl. Phys. A 75 (2002) 391-395.

[4] J.F. Pierson, A. Thobor-Keck, A. Billard, Cuprite, paramelaconite and tenorite films deposited by reactive magnetron sputtering, Appl. Surf. Sci. 210 (2003) 359-367.

[5] L. Kleiman, K. Mudnick, Nitrogen states in Ga(As,P) and the long-range, shortrange model: A systematic study, Physica Rev. B 21(8) (1980) 3478-3490.

[6] S.C. Ray, Preparation of copper oxide thin film by the sol- gel-like dip technique and study of their structural and optical properties, Sol. Energy Mater. Sol. Cells 68(3-4) (2001) 307-312.

[7] B. Balamurugan, B.R. Mehta, Optical and structural properties of nanocrystalline copper oxide thin films prepared by activated reactive evaporation, Thin Solid Films 396 (2001) 90-96

[8] T.J. Richardson, New electrochromic mirror systems, Solid State Ionics 165 (2003) 305-308.

[9] V.F. Drobny, D.L. Pulfrey, Properties of reactively-sputtered copper oxide thin films, Thin Solid Films 61 (1979) 89-98.

[10] F. Laquai, Materials for lasers: all-round perovskites, Nat. Mater. 13 (2014) 429-430.

[11] T. Leijtens, G.E. Eperon, S.A. Pathak, A. Abate, M.M. Lee, H.J. Snaith, Overcoming ultraviolet light instability of sensitized $\mathrm{TiO}_{2}$ with meso-superstructured organometal tri-halide perovskite solar cells, Nat. Commun. 4 (2013) 2885:18.

[12] M.I. Hossain, F.H. Alharbi, N. Tabet, Copper oxide as inorganic hole transport material for lead halide perovskite based solar cells, Solar Energy 120 (2015) 370-380.

[13] C. Zuo, L. Ding, Solution-processed $\mathrm{Cu}_{2} \mathrm{O}$ and $\mathrm{CuO}$ as hole transport materials for efficient perovskite solar cells, Small 11(41) (2015) 5528-5532.
[14] S. Chatterjee, A.J. Pal, Introducing $\mathrm{Cu}_{2} \mathrm{O}$ thin films as a hole-transport layer in efficient planar perovskite solar cell structures, J. Phys. Chem. C 120(3) (2016) 1428-1437.

[15] B.A. Nejand, V. Ahmadi, S. Gharibzadeh, H.R. Shahverdi, Cuprous oxide as potential low-cost hole-transport material for stable perovskite solar cells, Chem. Sus. Chem. 9(3) (2016) 302-313.

[16] W. Yu, F. Li, H. Wang, E. Alarousu, Y. Chen, et al., Ultrathin $\mathrm{Cu}_{2} \mathrm{O}$ as an efficient inorganic hole transporting material for perovskite solar cells, Nanoscale 8(11) (2016) 6173-6179.

[17] M.I. Hossain, F.H. Alharbi, Recent advances in alternative material photovoltaics, Mater. Technol.: Adv. Perform. Mater. 28 (2013) 88-97.

[18] T. Minami, T. Miyata, Y. Nishi, $\mathrm{Cu}_{2} \mathrm{O}$-based heterojunction solar cells with an $\mathrm{Al}$ doped $\mathrm{ZnO}$ /oxide semiconductor/thermally oxidized $\mathrm{Cu}_{2} \mathrm{O}$ sheet structure, Sol. Energy 105 (2014) 206-217.

[19] Y.S. Lee, J. Heo, M.T. Winkler, S.C. Siah, S.B. Kim, et al., Nitrogen-doped cuprous oxide as a p-type hole transporting layer in thin-film solar cells, J. Mater. Chem. A 1 (2013) 15416-15422.

[20] F. Biccari, Defects and doping in $\mathrm{Cu}_{2} \mathrm{O}$, A thesis submitted in partial fulfillment of the requirements for the degree of doctor of philosophy in physics, Sapienza Universita di Roma, Italy, 2009.

[21] S.W. Lee, Y.S. Lee, J. Heo, S.C. Siah, D. Chua, Improved $\mathrm{Cu}_{2} \mathrm{O}$-based solar cells using atomic layer deposition to control the $\mathrm{Cu}$ oxidation state at the p-n junction, Adv. Energy Mater. 4(11) (2014) 1301916:1-7.

[22] D.O. Scanlon, B.J. Morgan, G.W. Watson, Modelling the polaronic nature of $p$ type defects in $\mathrm{Cu}_{2} \mathrm{O}$ : the failure of GGA and GGA+U, J. Chem. Phys. 131 (2009) 124703:1-8

[23] M.C. Biesinger, P.B. Payne, Resolving surface chemical states in XPS analysis of first row transition metals, oxides and hydroxides: $\mathrm{Cr}, \mathrm{Mn}, \mathrm{Fe}, \mathrm{Co}$ and $\mathrm{Ni}, \mathrm{Appl}$. Surf. Sci. 257 (2011) 2717-2730.

[24] A.M. Smith, S. Nie, Semiconductor nanocrystals: structure, properties, and band gap engineering, Acc. Chem. Res. 43 (2010) 190-200.

25] S.C. Siah, Y.S. Lee, Y. Segal, T. Buonassisi, Low contact resistivity of metals on nitrogen-doped cuprous oxide $\left(\mathrm{Cu}_{2} \mathrm{O}\right)$ thinfilms, J. Appl. Phys. 112 (2012) 084508:1-5

[26] C. Malerba, C.L. Ricardo, M. D'Incau, F. Biccari, P. Scardi, A. Mittiga, Nitrogen doped $\mathrm{Cu}_{2} \mathrm{O}$ : a possible material for intermediate band solar cells?, Sol. Energy Mater. Sol. Cells 105 (2012) 192-195.

[27] L.J. Van der Pauw, A method of measuring specific resistivity and hall effect of discs of arbitrary shape, in: Semiconductor devices: Pioneering papers, World Scientific, World Scientific Publishing Co., Inc., NJ, USA, 1991, pp.174-182.

[28] G.D. Mey, X. Burvenich, M. De, Molder influence of sample geometry on magnetoresistance measurements, Phys. Stat. Sol. 23 (1974) 1045-1048

[29] K. Matsuzaki, K. Nomura, H. Yanagi, T. Kamiya, M. Hirano, H. Hosono, Epitaxial growth of high mobility $\mathrm{Cu}_{2} \mathrm{O}$ thin films and application to $\mathrm{p}$-channel thin film transistor, Appl. Phys. Lett. 93(20) (2008) 202107:1-3.

[30] D.S. Darvish, H.A. Atwater, Epitaxial growth of $\mathrm{Cu}_{2} \mathrm{O}$ and $\mathrm{ZnO} / \mathrm{Cu}_{2} \mathrm{O}$ thin films on $\mathrm{MgO}$ by plasma-assisted molecular beam epitaxy, J. Cryst. Growth 319 (2011) 39-43.

[31] J. Li, Z. Mei, L. Liu, H. Liang, A. Azarov, et al., Probing defects in nitrogen-doped $\mathrm{Cu}_{2}$ O, Sci. Rep. 4 (2014) 7240:1-6.

[32] T. Minami, Y. Nishi, T. Miyata, Impact of incorporating sodium into polycrystalline p-type $\mathrm{Cu}_{2} \mathrm{O}$ for heterojunction solar cell applications, Appl. Phys. Lett. 105 (2014) 212104:1-5.

[33] T. Bordjiba, M. Mohamedi, L.H. Dao, B. Aïssa, M.A. El Khakani, Enhanced physical and electrochemical properties of nanostructured carbon nanotubes coated microfibrous carbon paper, Chem. Phys. Lett. 441 (2007) 88-93.

[34] B. Aïssa, M.A. El Khakani, The channel length effect on the electrical performance of suspended-single-wall-carbon-nanotubes-based field effect transistors, Nanotechnology 20 (2009) 175203:1-9.

[35] V. Le Borgne, P. Castrucci, S. Del Gobbo, M. Scarselli, M. De Crescenzi, et al Enhanced photocurrent generation from UV-laser-synthesized-single-wallcarbon-nanotubes/n-silicon hybrid planar devices, Appl. Phys. Lett. 97 (2010) 193105:1-3.

[36] B. Aïssa, Z. Hamoudi, H. Takahashi, K. Tohji, M. Mohamedi, M. A. El Khakani, Carbon nanohorns-coated microfibers for use as free-standing electrodes for electrochemical power sources, Electrochem. Commun. 11(4) (2009) 862-866. 